\title{
Unusual MRI findings in a case of Marchiafava Bignami disease
}

Figure MRI performed 9 days after the onset of neurologic symptoms before supplemental treatment was initiated
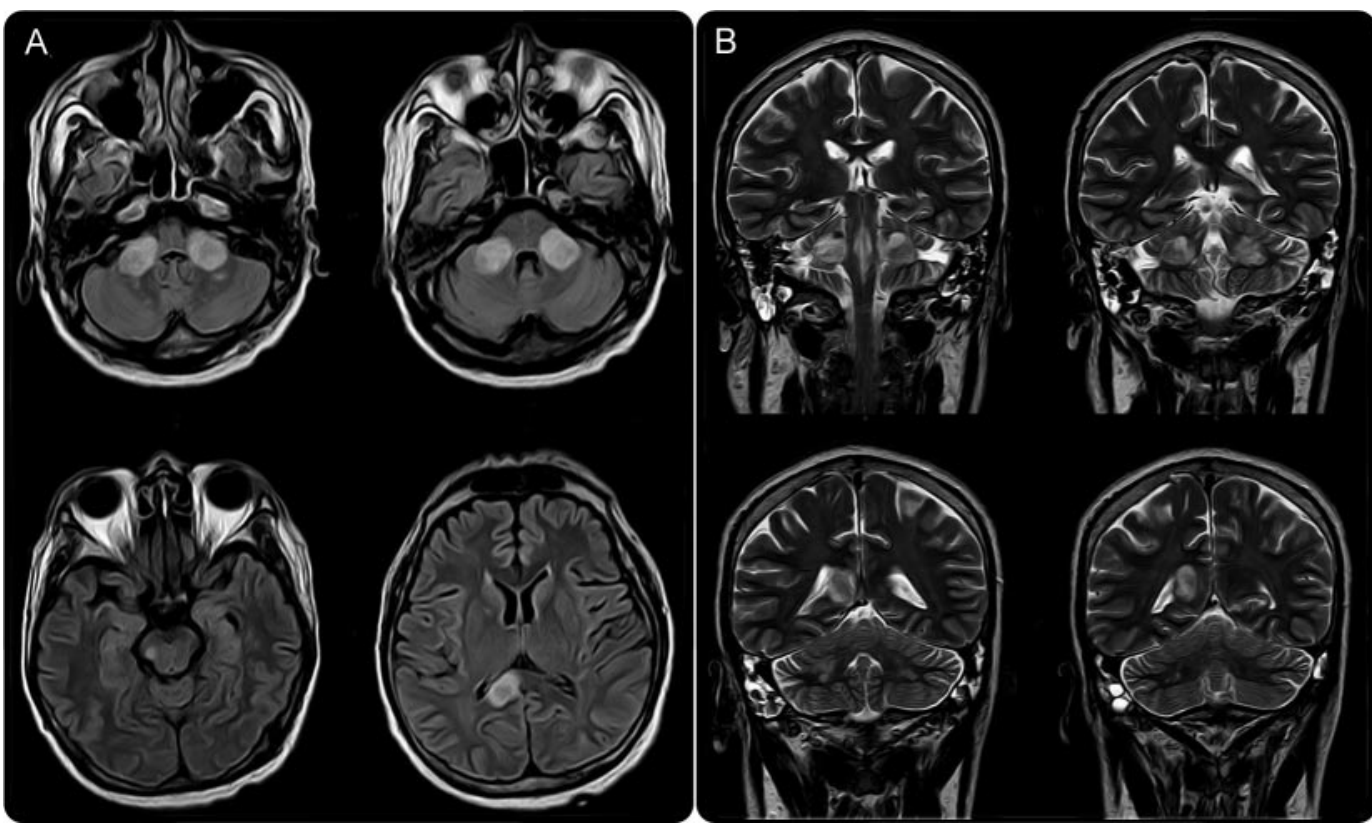

(A) Fluid-attenuated inversion recovery-weighted axial MRI shows hyperintense signal in medial cerebellar peduncles, right cerebral peduncle, and right splenio of corpus callosum. (B) T2-weighted coronal MRI shows increased signal intensity in the same structures.

Twenty-four hours after surgery for acute aortic dissection, a 51-year-old man with alcoholism developed agitation, decreased consciousness, mutism, and upbeat nystagmus on upward gaze. He also showed left-sided weakness with pyramidal signs and spastic limb ataxia. After 4 weeks treatment with thiamine supplementation, his neurologic and general condition improved. MRI findings are shown in the figure.

Marchiafava Bignami disease is associated with chronic alcoholism and nutritional deficiency. ${ }^{1,2}$ Although etiopathogenesis is unknown, alcohol toxicity and osmotic disorders are in relation with typical corpus callosum demyelination. Other CNS structures such us white matter tracts and middle cerebellar peduncles may be involved, but far less frequently.

\section{S. Bellido, MD, I. Navas, MD, M.A. Aranda, MD, R. Ginestal, MD, B. Venegas, MD, Madrid, Spain}

Author contributions: Dr. Bellido: drafting/revising the manuscript, study concept or design, analysis or interpretation of data. Dr. Navas: drafting/revising the manuscript, study concept or design, analysis or interpretation of data. Dr. Aranda: drafting/revising the manuscript, study concept or design, analysis or interpretation of data. Dr. Ginestal: drafting/revising the manuscript, study concept or design, analysis or interpretation of data. Dr. Venegas: drafting/revising the manuscript, study concept or design, analysis or interpretation of data.

The authors report no disclosures relevant to the manuscript. Go to Neurology.org for full disclosures.

Correspondence \& reprint requests to Dr. Bellido: sara.bellido@gmail.com

1. Okamoto K, Tokiguchi S, Furusawa T, et al. MR features of diseases involving bilateral middle cerebellar peduncles. AJNR Am J Neuroradiol 2003;24:1946-1954.

2. Tung CS, Wu SL, Tsou JC, et al. Marchiafava Bignami disease with widespread lesions and complete recovery. AJNR Am J Neuroradiol 2010;31:1506-1507. 


\section{Neurology}

\section{Unusual MRI findings in a case of Marchiafava Bignami disease}

S. Bellido, I. Navas, M.A. Aranda, et al.

Neurology 2012;78;1537

DOI 10.1212/WNL.0b013e3182553ced

\section{This information is current as of May 7, 2012}

\section{Updated Information \&} Services

References

Subspecialty Collections

Permissions \& Licensing

Reprints including high resolution figures, can be found at: http://n.neurology.org/content/78/19/1537.full

This article cites 2 articles, 1 of which you can access for free at: http://n.neurology.org/content/78/19/1537.full\#ref-list-1

This article, along with others on similar topics, appears in the following collection(s):

Alcohol

http://n.neurology.org/cgi/collection/alcohol

Coma

http://n.neurology.org/cgi/collection/coma

Metabolic disease (inherited)

http://n.neurology.org/cgi/collection/metabolic_disease_inherited MRI

http://n.neurology.org/cgi/collection/mri

Information about reproducing this article in parts (figures,tables) or in its entirety can be found online at:

http://www.neurology.org/about/about_the_journal\#permissions

Information about ordering reprints can be found online:

http://n.neurology.org/subscribers/advertise

Neurology $®$ is the official journal of the American Academy of Neurology. Published continuously since 1951 , it is now a weekly with 48 issues per year. Copyright Copyright (C) 2012 by AAN Enterprises, Inc.. All rights reserved. Print ISSN: 0028-3878. Online ISSN: 1526-632X.

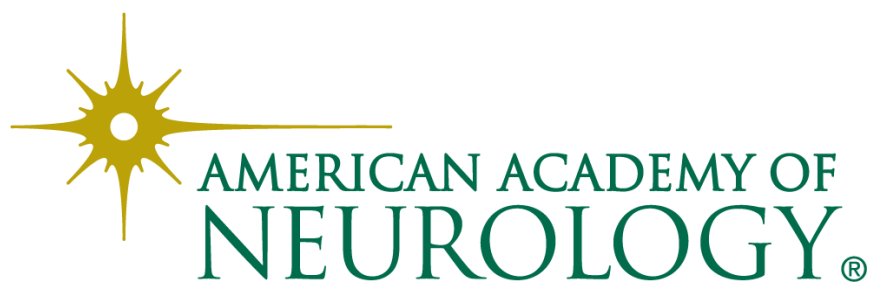

